Summer 2010

\title{
Learning Commons: Addressing the Needs of Commuter Regional Campuses
}

\author{
Nancy H. Dryden \\ University of Connecticut, nancy.dryden@uconn.edu \\ Shelley G. Roseman \\ University of Connecticut, shelley.goldstein@uconn.edu
}

Follow this and additional works at: https://opencommons.uconn.edu/libr_pubs

Part of the Library and Information Science Commons

\section{Recommended Citation}

Dryden, Nancy H. and Roseman, Shelley G., "Learning Commons: Addressing the Needs of Commuter Regional Campuses" (2010). Published Works. 38.

https://opencommons.uconn.edu/libr_pubs/38 


\author{
Learning Commons: \\ Addressing the Needs of Commuter Regional Campuses \\ Nancy H. Dryden \\ Director, Regional Campus Libraries \\ University of Connecticut \\ Shelley G. Roseman \\ Director, Waterbury Campus Library \\ University of Connecticut
}

\begin{abstract}
The Learning Commons concept in academia is now fairly mainstream and in the evaluation phase at many institutions. This model is gradually making its way into non-residential campuses and proved to be a challenge for five regional libraries of a state university who sought to establish user-centered environments on a shoe-string budget and tight quarters. These Learning Commons initiatives addressed the needs of urban, suburban, and rural based libraries whose student populations ranged from under 300 to nearly 2,000 . While there was no single model to address student needs at all campuses, there were commonalities in users' expectations that guided the process and allowed the libraries to seamlessly integrate new services in support of student learning. This case study describes the tools used to gauge the needs of the University of Connecticut's regional campus users to enable the libraries to launch learning commons that reflected the unique needs of non-residential users.
\end{abstract}

\title{
Adapting the Learning Commons Model
}

The Regional Campus Libraries at the University of Connecticut were charged with proposing Learning Commons plans for its five regional campuses which cater exclusively to commuter students. The campuses are now bringing together much of the new technology and services that these students require to complete their assignments, thereby adapting the Learning Commons model to meet unique student populations.

In defining "regional campus libraries," this case study adhered to the National Center for Education Statistics (NCES) designation as described in Brandt, Frederiksen, Schneider, \& Syrkin (2006), referring to permanent facilities within a "commuting distance" offering distinct majors and both undergraduate and graduate programs.

By focusing on the specific climate of each campus, space was reinvented to address the needs of nonresidential students within urban, suburban, and rural settings. Incorporating commons service models into regional academic libraries meant addressing the diverse needs of commuters and non-traditional learners who often sought quiet above all else as they breezed in and out of campus, yet required occasional group space for projects; and by providing effective one-desk support that addressed reference, writing, and technical support.

\section{Literature Review}

Identifying learning commons literature that addressed the needs of students who are rarely on campus for more than the time they have to spend in classes, yet often sought quiet or group study space in between jobs and homes, required some digging. Surprisingly, there was a substantial lack of material where commuter campuses were concerned in view of the fact that that approximately 86 percent of college and university students were defined as commuter students - "that is, students not living in university-owned housing." (Tenhouse, 2002) Sloan reports that "half the nation"s twenty million college students" are considered commuters."(Sloane, 2008) Lack of 
literature may be linked to the fact that regional libraries are often considered "second-class citizens" in the library system if the target audience is undergraduates who don't typically pursue "research."(Webb, 2000, p. 87)

The "Information Arcade" at the University of Iowa (Creth \& Lowry, 1994) transformed thousands of square feet of space with a generous six figure grant and involved numerous stakeholders (Lowry, 1994). This may well have paved the way for the abundance of literature that ensued on the learning commons concept, however much of this literature describes collaborative environments among larger residential universities. A review of the literature using alternating terms of "learning commons" and "information commons" (Beagle, Russell, \& Bailey, 2006) was replete with scenarios comparable to that of the University of Iowa. In searching for "blended learning" (Garrison \& Kanuka, 2004) and its applications to commuter libraries, again the literature review was disappointing with regard to a commuting student population. Bierce Library at the University of Akron (Franks \& Tosko, 2007) addresses diversity within the Learning Commons model and includes "a significant number of adult learners and evening students" in its model to some degree. Because diversity of user population is what defines regional campuses, their focus on diversity of ability was not applicable. Ohio University did not initially include regional campuses in learning commons planning in 2004. They subsequently introduced a regional campus learning commons in response to "an increased need for a gathering place for students since they do not have residence halls." (Ohio University Chillicothe's learning commons, 2007)

Although the enrollment and culture greatly deviated from that of the regional campuses at the University of Connecticut, planning efforts relied heavily on the unpublished plan of the University of Connecticut Learning Commons Project Team, which focuses on the needs tof the main campus in Storrs. The plan, as with so many others during the past decade, was guided by Lippincott's mission of a learning commons: "to leverage the intersection of content, technology, and services in a physical facility to support student learning." (Lippincott, 2006) Main campus findings provided much insight into the survey literature that subsequently impacted the regional campuses' initiatives.

\section{Learning Commons Project: Main Campus}

The University of Connecticut (UConn) is a research intensive university and the state's flagship institution of higher learning with enrollment of over 29,000 students. The UConn Libraries consist of 2.7 million volumes and over 91,000 currently received print and electronic journals across six campuses, with the main campus library, the Homer Babbidge Library (Babbidge), housing the majority of the holdings. Babbidge was built in 1978 and completed a $\$ 40$ million renovation in 1998 and is located at the center of the Storrs academic core, serving both graduate and undergraduate programs.

The genesis of the Learning Commons projects at the regional campuses grew out of the successful beginnings of an initiative at the main campus library. A team of staff members from the UConn Libraries and the Institute for Teaching and Learning (ITL) was formed in late May 2006 to build on the elements of a Learning Commons that were already in place on Level I of Babbidge. These elements included: a large computer lab, internet cafes, hands-on information technology training rooms, wireless Internet, IT support, and reference and research services. The team shared the concept with various components of the university community to obtain feedback and suggestions and to develop partnerships. They learned that there was a strong interest in consolidating academic support services, for creating learning spaces outside of classrooms, and that the commons be a support mechanism for the General Education competencies skills that are required of all undergraduate students. These competencies include computer technology, writing, quantitative skills (Q), second language proficiency, and information literacy.

Funding for the Babbidge Learning Commons started with the project team partnering with the University Foundation. They began by identifying three specific aspects of the Commons that would be targets of the fundraising: iStudios (group study rooms with collaborative workstations), tutoring studios, and Media Studios (studios for editing digital media projects). Specific alumni class gifts and target amounts were established. As space for the Writing Center, Q tutoring, and the Learning Resource Center (LRC) was made available for campus partners to bring these outside units into the Library, those partners contributed furniture and equipment as appropriate. In addition, the team received funds from the UConn Libraries' equipment budget to fund iStudio workstations. 


\section{Regional Campuses}

In addition to the main campus in Storrs, CT, there are five regional campuses across the state: Avery Point, Greater Hartford, Stamford, Torrington, and Waterbury. All campuses started as "feeder schools" to the main campus where students completed their first two years of an undergraduate degree at the regional campus before transferring to Storrs, and they still serve in that capacity as well as now offering undergraduate four year degrees and seven graduate degrees at four of the campuses. The source of enrollment data used in planning was generated by the University's Office of Institutional Research. (University of Connecticut Office of Institutional Research, 2007) In the fall of 2009, the regional campuses served nearly 21 percent of the undergraduate enrollment at UConn and 32 percent of the graduate enrollment (not including the Health Center and Law School). Each campus has its own identity, serving traditional and non-traditional students at various locations across the state.

The Avery Point campus, located on the Long Island Sound in southeastern Connecticut, has a focus of marine sciences and maritime studies. It enrolls 713 undergraduates and offers four- year degrees in Coastal Studies, Maritime Studies, American Studies, and a Bachelor of General Studies (BGS). There are 38 students in the graduate program in the Marine Sciences department, which also supports the Coastal Studies program. (Heckman \& Heckman, 2009)

The Greater Hartford campus, in suburban West Hartford, has a focus on metropolitan issues, public policy, and health policy. There are 1,299 undergraduate students and available majors include: BGS, Business and Technology, Human Development and Family Studies (HDFS), Psychology, and Urban and Community Studies. Two master's programs in Public Policy, an MSW and PhD in Social Work, the Teacher Certification Program for College Graduates (TCPCG), and an MBA, EMBA (Executive MBA), and MS in Accounting account for 1,470 graduate students.

The campus in urban Stamford enrolls 1,294 undergraduate students and has had four- year majors since the 1970's. Currently available degrees include American Studies, BGS, Business and Technology, HDFS, Economics, History, English, Political Science, and Psychology. There are 492 students in the MBA program. The focus of the Stamford campus is International, Business, and selected arts and sciences programming.

The smallest campus, Torrington, is in the northwest corner of the state and currently enrolls 273 students. The rural campus' focus is arts and humanities and there are no graduate programs offered. Students can complete bachelor's degree programs in American Studies, BGS, Business and Technology, HDFS, Psychology, and Urban and Community Studies.

Another urban campus is Waterbury and its focus is on Civic and Community Engagement. There are 909 undergraduate students and the campus offers majors in American Studies, BGS, Business and Technology, HDFS, English, Psychology, and Urban and Community Studies. There are 120 students in the MBA program and 18 students in the TCPCG.

Each regional campus has its own library, with volume counts from 16,000 to nearly 100,000 , operating primarily as a public service operation for its campus. Together with Babbidge, these UConn Libraries share a single catalog and form a single collection; each library unit serves as a full gateway to the entire collection. The Libraries' networked resources, including databases, journals, books, and reference tools, are available to all members of the University community via the Internet.

\section{Extending the Learning Commons to the Regional Campuses}

In the spring of 2007, staff at the Regional Campus Libraries (RCL) began consulting with the main campus Learning Commons Project Team. The RCL Learning Commons Team was formed with a membership of five RCL Directors, two staff members, and the RCL's Area Head. By June 2007, the RCL staff had created a goal for the Area, "to develop plans for transforming student learning spaces" understanding that these would most likely vary from library to library. The team created a Project Plan that included information gathering, conversations with communities, and planning and development phases (Appendix A). On June 5, RCL Directors and other staff members attended a Northeast Regional Computing Program (NERCOMP) Special Interest Group (SIG) workshop called Uncommon Commons in Norwood, Massachusetts to learn how four libraries had used the concept of the 
"commons" in unique ways. Team members surveyed local libraries and made site visits to local university libraries. Throughout the next six months, members of the main campus' LC Project Team made "road show" visits to each campus to educate various campus constituencies, sharing insight based on their extensive research of what a learning commons is and the ways current students learn. This enabled directors at each RCL to have conversations with campus directors, faculty, students and staff in student services, writing center and tutoring services, IT, and the library.

\section{Creating a Survey}

Because students at the regional campuses commute from various distances (there is no on-campus housing at any campus), the campuses were challenged to provide facilities and services that would accommodate the students' needs. The team believed, as Forrest and Halbert (2009) later said that, "...like politics, all information commons are local." The next step for trying to ascertain how a learning commons could work in the specific environments of regional campuses was to conduct a survey.

Initially, the team crafted a survey that focused on the libraries and discussed the idea of doing a different survey for each campus. The team shared a draft of the survey with writing center and student services staff at the campuses and decided that a survey that included questions about the other learning components would be more useful. At this point, the learning commons concept became a collaborative initiative, helping to set aside the issues of funding source or staffing the units. There was noticeable campus buy-in once the intent of the survey was clarified: to discover how students used various campus services and how they felt the services could be improved. Sections in the survey (Appendix B) included: Research and Studying Environment; Library; Writing Center; Tutoring Services; and Technology. The survey was administered in January 2008 using SurveyMonkey software. An email was sent to nearly 5,800 undergraduate and graduate students via listservs at each campus including a link for the survey (Appendix C).

\section{Results of the Survey}

RCL staff analyzed and tabulated the data and distributed the results to other campus constituencies. The survey yielded a surprisingly high response rate of 17 percent among enrolled students, representing the preferences of some 75 percent of undergraduates and 25 percent graduate students. Forty nine percent of the undergraduates were first-year students. Of the 30 questions, the first three were demographic, relating to respondents' status, years of attendance, and primary campus affiliation. The remaining questions were in a Likert-type format to measure students' satisfaction and preferences with regard to the library, writing center, tutoring services, and technology support. The survey included one open-ended question per section allowing respondents the opportunity to suggest improvements. As with many residential campus students, the sampling of the commuters showed preferences for extended hours, liberal food policies, and collaborative learning environments. There was also an expectation of one-stop access so that tutoring and technical support would fall within the confines of the library.

With a 79 percent satisfaction rating, the regional libraries were clearly in a positive zone. The survey verified that students used the library primarily to study or use computers. Computer use was equally divided between classroom tasks and personal/recreational use. Of the 454 open-ended responses generated in response to "Please let us know what we can do to improve your research and studying environment," nearly 30 percent expressed the need for more lenient food and beverages policies. Of significant concern, representing nearly half of the comments, were complaints over excessive noise and shortage of study rooms. Some 75 comments sought additional computers with larger work areas and access to electrical outlets. Forty five comments suggested more comfortable furnishings and enhanced lighting. Unlike students at residential campuses, regional respondents portrayed the library less as a social venue, and more as a much needed place to complete class assignments individually or collaboratively to complete group projects.

There were numerous expressed concerns with the writing center and tutoring services, with 30 percent and 24 percent satisfaction rating (respectively). When asked "How many times do you use the writing center (or tutoring services) in the course of an academic year?" 65 percent of respondents indicated "not at all." While 375 and 228 (respectively) reported limited writing and tutoring center use due to insufficient staffing, hours, and lack of visibility, a comparable percentage reported that "I don't need writing/tutoring help." Of the 259 open-ended comments inquiring about improvements to the writing center, 25 percent suggested the need to publicize the center 
and to make it more accessible. The 219 open-ended comments relating to tutoring services voiced comparable concerns. From these results, it seemed evident that providing more visibility to these services would enhance use and promote increased satisfaction among students.

Technical support services on campuses had a 57 percent satisfaction rate among respondents. Respondents indicated comparable use of campus computers for course assignments /web management system and personal /recreational use. Unlike responses for other campus units, the 31 open-ended responses inquiring about improvements for technical support included only discipline specific software suggestions rather than enhanced services. From these results, it seemed evident that students considered themselves technology veterans and were not interested in classes or workshops to enhance or learn new skills.

\section{Next Steps}

The survey indicated that students were receptive to the idea of a learning commons that would provide enhanced library resources, improved furnishings, and tutoring and technology services. Each of the five regional libraries proceeded with a plan unique to their campus, within a short period of time and limited funding, sharing some commonalities that included

- Aggressive weeding to open up space within the library,

- Increased collaborative learning opportunities,

- More lenient food and drink policies,

- Upgraded library terminals to include MS desktop applications software,

- One-desk service to replace traditional reference desks,

- Enhanced signage,

- Established collaboration with writing/tutoring centers,

- Upgraded furnishings, and

- Emphasis on optimizing space without undergoing extensive remodeling/construction.

\section{Planning at each Campus}

As each regional campus has its own identity and academic focus, so too each regional campus library's efforts towards introducing Learning Commons components onto its campus would vary. In some ways, the facilities in Stamford and Waterbury, the urban campuses, were out in front as they had newer buildings. The libraries at Avery Point, Greater Hartford, and Torrington were in older buildings; the Avery Point library was built in the 1930's and Greater Hartford and Torrington in the 1960's, with little renovation and minimal upgrading to furnishings in the interim. Thus, Stamford's library, built as part of the larger, one-block campus in 1998, included several group study spaces, data jacks, wireless connectivity (by 2001), and soft-seating areas. Waterbury's campus, built in 2003, included a library with pop-out data and electrical outlets on side tables, soft-seating areas, and group study rooms. However, both campuses require enhancements to better serve their users in a Learning Commons environment.

The Avery Point library was furnished in 1967 and had received minimal upgrading, including wiring for technology, air conditioning for the first floor only, and wireless access. There existed study tables and carrels, with a leaky skylight on the second floor, and only one group study room that included compact shelving for journals. In 2007 and 2008, library staff met with the Academic Center, comprised of tutoring and technology support, to discuss merging all units. The Academic Center, located in a separate building on campus, opted to remain in their current location. Staff from the library and the Center are currently collaborating in a variety of projects: a librarian serves an hour a day in the Center, student workers are cross trained, and the both units maintain a variety of web 2.0 tools. (Heckman \& Heckman, 2009) The Avery Point library is slated to receive $\$ 3$ million to upgrade the library building as part of a state plan. The library pledged to commit funds to upgrade furnishings on the first floor of the two-floor building in summer 2009. Soft-seating areas, individual carrels, café height tables, and a collaborative workstation with a 24 inch monitor currently fulfill some of the needs identified by students in the survey. Future enhancements include upgraded wiring throughout the library, two iStudios for the second floor, an electronic classroom, reduction of the stacks, and additional soft-seating. 
The Greater Hartford's library, named the Harleigh B. Trecker Library, was built in the mid-1960's and has also had little renovation and maintenance to the building for nearly four decades. The campus formed a Learning Commons Committee which was co-chaired by a librarian and an IT staff member in 2007. One year later, the committee concluded that it wasn't feasible to move the IT services, the writing center, tutoring support, student advising, and the library - scattered throughout the campus - into a single location. The committee recommended the development of a Virtual Learning Commons that would provide a portal to each function from the campus web page. The Trecker library created commons-like spaces by utilizing existing and donated furniture from a cafeteria on campus and by clearing out a room that had previously held library stacks. It created a large, wireless group study room, and extensive weeding of reference materials and print journals allowed for a "parlor" area with soft seating. The promise of repairing the roof of the library building became a reality and served as the impetus for the UConn Libraries to update the furnishings. A library services one desk was custom built and includes an area for a reference librarian, eliminating the separate reference desk area. In the spring of 2009 , the library received a makeover with new furniture and new signage. This included café tables and bright-colored chairs; single person study tables; a large group consultation table; several soft seating areas; chairs with laptop "tablets;" cloverleaf-shaped tables for computer workstations, carpeting, and vertical blinds. The second floor group study room received smaller reconfigurable tables and new chairs, a projection screen, and a projector to allow this room to be used for library instruction. The Libraries anticipate further upgrades, including wiring, iStudios, new stack ends, renovated group study rooms, and a renovated staff area.

In many ways, the Stamford campus has the most natural situation to create a learning commons. The campus is housed in one three-story building the size of a city block and has a street-side concourse. The library, café, bookstore, and art gallery all have first-floor entrances from the concourse and therefore are highly accessible. The campus computer lab, writing center, and the Source for Active Learning (tutoring center) were located on the $3^{\text {rd }}$ floor and less accessible. Library staff met with the campus director and staff from the Writing Center, Source, Student Services, and the Computer lab to discuss moving components into the spacious library. The Writing Center and the Source were very interested, as their current location was remote and could easily be moved. In the fall of 2007, initial collaboration included holding Writing Center workshops in the library electronic classroom. This classroom, the Thomson-Reuters eClassroom, was upgraded with a new teaching workstation, enhanced lighting, replacement laptops, and a new AMX control system. Subsequently, two new projectors were installed. In the spring of 2008, back journals were weeded to allow the removal of 16 stacks, and space was opened up to allow for the Writing Center and the Source which relocated to the corner of the first floor of the library. Future plans will explore the option of moving the computer lab into the library; building iStudios, tutoring, and media presentation rooms; upgrading furniture; and creating a central information desk that could house IT students as well as librarians.

The smallest campus, in Torrington, is in a building built in the 1960's with library furnishings that were no fresher. The Learning Center, which houses writing and tutoring services, had been renovated and is located across the hall from the library. Since the computer lab was situated nearby, combining services on such a small campus seemed impractical. The focus for the library then became upgrading the facility and furnishings. In spring 2008 , UC Libraries purchased soft seating, including an upholstered chair with a tablet arm, a collaborative table with a large monitor, and four task chairs. In fall 2009, the campus director enhanced this purchase with three study tables and twelve chairs, and in fall 2009 subsequently matched funding for computer cloverleaf workstation tables. The library has also put in place a collaborative effort with the Learning Center to cross-train staff members and student workers. Future needs include air conditioning, upgraded wiring, new lighting, and group study rooms.

The urban Waterbury campus, in one three-story building, was built in 2003. Because of a growing awareness of the Learning Commons concept, the Writing Center was placed within the library. Subsequently the Math Center relocated to the library as well because of limited space issues on campus. The Math Center room now serves a dual-purpose, as equipment was installed in 2008 and upgraded in 2009, it now permits instructional sessions within the library. There are soft seating areas, group study rooms, and laptop tablets, but the design of the library, with an atrium extending three floors, allows for a great deal of noise throughout necessitating more group study rooms. The comfortable furniture is now aging and wearing out and there is the need for larger work areas in the computing area. There is also the need to explore noise reduction/absorption systems to address ongoing patron concerns.

\section{Conclusion}


The General Education Oversight Committee (GEOC) at UConn has indicated that the "unofficial education of students should happen in the learning commons." (GEOC, 2009). At this point, the regional campuses have made strides toward creating learning commons reflecting their campus' needs. The effectiveness of the regionals' commons in addressing the learning needs of students requires assessment. Preliminary indicators of success are increased gate counts at all regional campuses; positive anecdotal feedback from students, faculty and campus administrators; expansion of the library's role in the writing process; and more effective use of library space for instruction. The regional campuses will be participating in the main campus' assessment initiatives. These will include surveys, filmed interviews, and student "monologues" in the spring of 2010. LibQual data from the 2011 survey will further serve to gauge user satisfaction.

\section{References}

Beagle, D. R., Russell, D., \& Bailey, B. T. (2006). The information commons handbook. New York: Neal Schuman.

Brandt, J., Frederiksen, L., Schneider, T., \& Syrkin, D. (2006). The face of regional campus libraries and librarianship. Journal of Library Administration, 45(1/2), 37.

Creth, S. D., \& Lowry, C. B. (1994). The information arcade: Playground for the mind. Journal of Academic Librarianship, 20(1), 22.

EDUCAUSE Center for Applied Research. (2007). ECAR study of undergraduate students and information technology. Retrieved December 6, 2009, from http://net.educause.edu/ir/library/pdf/EKF/EKF0906.pdf

Forrest, C., \& Halbert, M. (Ed.). (2009). A field guide to the information commons. Lanham, Maryland: Scarecrow Press.

Franks, J. A., \& Tosko, M. P. (2007). Reference librarians speak for users: A learning commons concept that meets the needs of a diverse student body. Reference Librarian, 47(97), 105-118.

Garrison, D. R., \& Kanuka, H. (2004). Blended learning: Uncovering its transformative potential in higher education. The Internet and Higher Education, 7(2), 95-105.

General Education Oversight Committee (GEOC). (2009). Meeting minutes. Retrieved December 6, 2009, from http://geoc.uconn.edu/Minutes/FA09_9-4-09_minutes.pdf 
Heckman, J. E., \& Heckman, M. V. (2009). Learning commons planning: One size does not fit all. International Association of Aquatic and Marine Science Libraries and Information Centers Conference, Retrieved December 6, 2009, from http://tinyurl.com/yc7sdk3

Lippincott, J. K. (2006). Linking the information commons to learning spaces. In D. Oblinger G. (Ed.), Learning spaces. Retrieved December 12, 2009, from http://www.educause.edu/ir/library/pdf/PUB7102g.pdf

Lowry, A. K. (1994). The information arcade at the University of Iowa. CAUSE/EFFECT, 17(3), Retrieved December 14, 2009, from http://net.educause.edu/ir/library/text/CEM9438.txt

Ohio University Chillicothe's learning commons. (2007, January 18). Retrieved December 14, 2009, from http://www.ohio.edu/outlook/06-07/January/265n-067.cfm

Schneider, T. M. (2001). The regional campus library and service to the public. The Journal of Academic Librarianship, 27(2). Retrieved December 6, 2009, from http://tinyurl.com/ygjrpq2

Sloane, W. (2008, May 13). Views: The bachelor's degree is obsolete? Inside Higher Ed, Retrieved December 6, 2009, from http://www.insidehighered.com/views/sloane/sloane20

Tenhouse, A. M. (2002). Commuter students. In J. W. Guthrie (Ed.), Encyclopedia of education (2nd ed., pp. 451). New York: Macmillan Reference USA. Retrieved December 14, 2009, from Gale Virtual Reference via Gale http://tinyurl.com/ycwqalc

University of Connecticut Office of Institutional Research, Division of Enrollment, Planning, Management. UConn Fact books. Retrieved December 9, 2009, from http://www.oir.uconn.edu/factbook.html

Webb, T. D. (2000). Building libraries for the 21 st century: The shape of information. Jefferson: McFarland \& Company, Inc. 


\section{Learning Commons Task Force \\ Regional Campus Libraries \\ Project Plan Outline}

Phase 1. Information Gathering

A. Environmental Scan for best practice

1. Literature review

2. Learning Commons site visits

a. In-person

b. Virtual

3. Create surveys - could be different for each library

B. Attend conferences and programs

C. Consult with key people at Storrs

1. Scott Kennedy, LC Project Manager, HBL

2. Dave Avery, Facilities Librarian, HBL

3. Steven Park, LRC Manager, HBL

4. Kim Chambers, Director, Educational Technologies (ITL), Storrs

5. Tony Molloy, IT Support Services, HBL

D. Consolidate information gathered [END OF AUG. 2007]

Phase 2. Conversation with Communities

A. Identify people to involve at each campus

B. Presentation by Scott, Kim and Steven to each campus

C. Meet with groups and key players

1. Writing Center

2. Campus IT staff

3. Tutoring services

4. SGA and other student groups

5. Campus director

6. Library staff

7. Student services staff

D. Conduct survey and tabulate information (Jan.-Feb. 2008)

E. Conduct focus groups

F. Consolidate information gathered [Fall 2008]

Phase 3. Planning and Development for each library

A. Meet again with partners on campus

B. Create vision and goals

C. Define services and decide on LC components to include

D. Consult with BKM interior designer

E. Decide on locations

F. Cost estimates

1. personnel

2. equipment and software

3. wiring

4. furniture

5. renovations

G. Draw up floor plans [Spring 2008] 


\section{Appendix B}

\section{UConn Regionals: Learning Commons Survey \\ 1. SURVEY INTRODUCTION}

We want to find out your experiences with the lbrary, writing, tutoring, and seconology services on camcus and ask that you complete this brief suvey. The intomation that you provide with help us plan the Learning commons, where students will be able to find services that enhance fearning, writing, research, and teaching.

The suvey has 28 questions. Answering the mulipte choice questions should teke approximately 10 minutes. We welcome your suggestions at the end of each section. After submitring the survey, enter your Huskymal email address (which will be kept confidential and will not be linked to your survey response) for the rafte. The wirnes of the Pod Nanos (one per regional campus) will be notifed by emait.

IMPORTAVT: Cicking the "Next" button on each page will save your ansuges; if you want to go back bo previous pages to change your answets, you may do so by clicking on the "Prev" butzor on your internet browser. However, once you click "Done" on the "inal page of the survey, your answers will be sent and you will not be able to make changes.

Thank you for your time!

1. Please indicate your status:

vacerato

Matsers

2. Dottoral

\section{How long have you attended UConn?}
O. Y vara
2 wears
4. yeare

\section{Your Primary UConn Campus:}

Arery

Grester Hartare

Stantoro

Storrs

Fis Torration

Waternusy

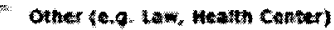

\section{A. RESEARCH AND STUDYTNG ENYTRONMENT}

4. Where do you prefer to work on assignments when you are on campus? (check all that apply)

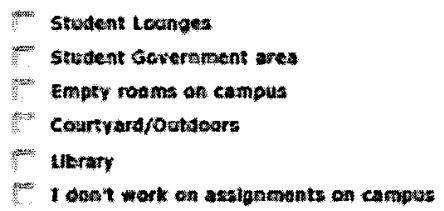




\section{UConn Regionals: Learning Commons Survey}

5. How important are the following to you when you work on assignments alone? (check all that apply)

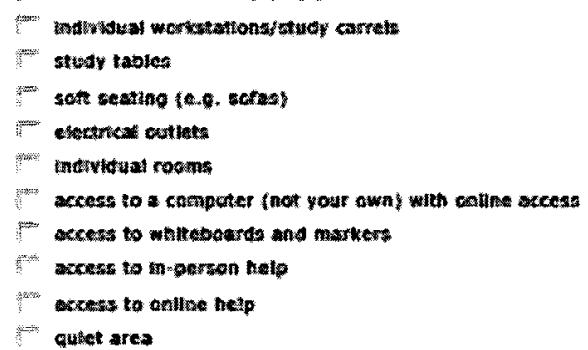

6. Please let us know what we can do to improve your research and studying environment.

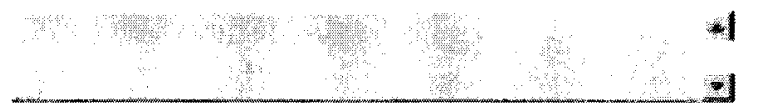

\section{B. LIBRARY}

7. How satisfied are you currently with your learning experience at the library?

Very sathatied

sationed

5. Samewhot saturied

- undedate

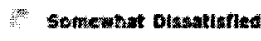

1 . Vary pikatistied

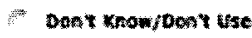

8. How many times do you typically use the library in the course of an academic year?

A) Ameat every day

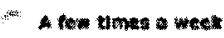

A rew umes a month

A few tums o semester (1 33$)$

Haybe ance or twoe

wot a all 


\section{UConn Regionals: Learning Commons Survey}

9. Where do you prefer to work on assignments when you are in the library? (check all that apply)

F. Computer werketations

Fivaly roomen

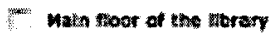

H. Upper Acors ef the barary

Hot. Stusty tables in the throry

- comcienstwor carres in Livary

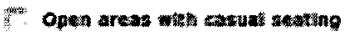

I dont work on asstparaents in the whary

10. Indicate reasons why you haven't used the library. (check all that apply)

in Locattan inconyenteat

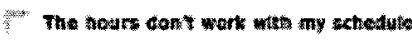

20. There wasn't anyone to helo me when I went

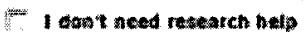

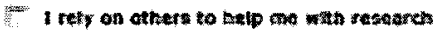

I use the thraxy

11. Indicate the services/resources expected from the library (check all that apply)

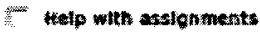

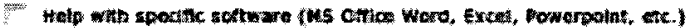

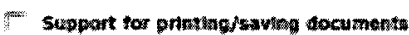

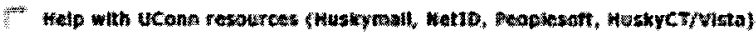

Fowe resounces vor paper:

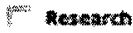

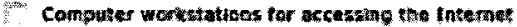

Wornoter worktations for wring pupers

1. Growp nudy space

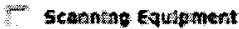

6. Taximp Equipment

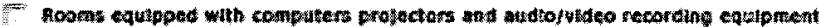

Study space tat anter ubrary bouss

12. Please let us know what we can do to improve your research and studying environment at the library.

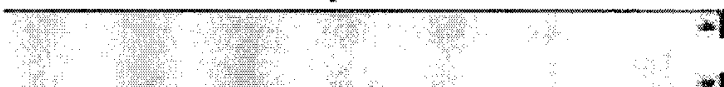

4. C. WRTTING CENTER 


\section{UConn Regionals: Learning Commons Survey}

13. How satisfied are you currently with the writing center services?

* Vert sutshed

Sationthed

Semermat Sotastred

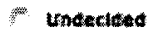

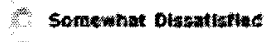

1*: Very Dlastatustited

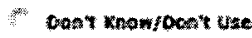

14. How many times do you typically use the writing center in the course of an acadenic year?

once week

A tew times a morth

4. A faw tumes a swawater $(1 \cdot 3)$

F May once cr twke a vear

*. not as all

15. Indicate reasons why you haven't used the writing center? (check all that apply)

- Losation to inconventent

The Tean cont wart wath my sethedulie

2. There waxh 1 anyone to help me when I went

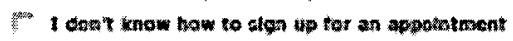

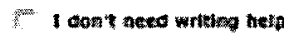

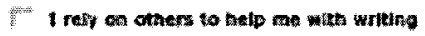

I I didst know we had a writh center

I the wring center

16. Indicate the services expected from the writing center (check all that apply)

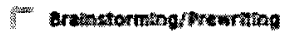

Thes statement

Reristion

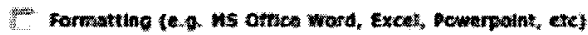

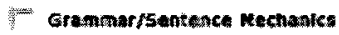

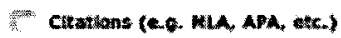

1. Finding and uttag tources in papers

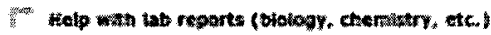

Other (okense specty)

17. Are you aware that the writing center offers workshops on common writing issues?

* $\operatorname{ves}$

wo 
UConn Regionals: Leaming Commons Survey

18. Please let us know what we can do to improve the writing center.

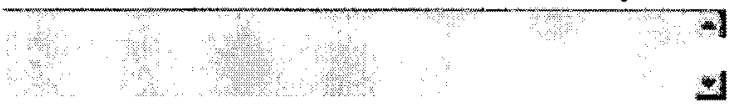

5. D. TUTORING SERVICES

19. How satisfied are you currently with tutoring services?

very sakthine

satrinted

Sonvewast Satuxted

uncected

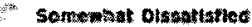

Very thaskeflod

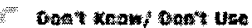

20. How many times do you typically use tutoring services in the course of an academic year?

the oncen weak

A A row times a monta

A trw thes a semester $(1 / 3)$

Marbe cace twite a rast

5) wot all

21. Indicate reasons why you haven't used the tutoring services? (check all that apply)

Focation is Inconventest

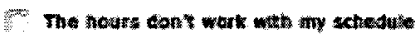

Fe There wasnt anyone to betp ne wen I wert

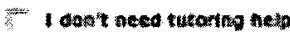

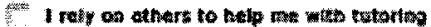

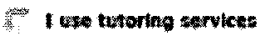

22. Indicate the services expected from the tutoring center (check all that apply)

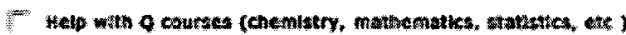

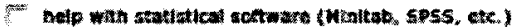

other

Othot (plowste specty)

23. Please let us know what we can do to improve the tutoring services.

a

9

6. E. TECHNOLOGY 


\section{UConn Regionals: Learning Commons Survey}

24. How satisfied are you currently with your technical support services on campus?

Vory sastaned

sined

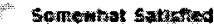

vatecioed

Fichewhet

Fotsutionted

Vers Diswatistied

Davt know Dont ves

25. What tasks do you routinely perform on a computer while you are on campus? (check all that apply)

Tmala

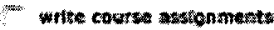

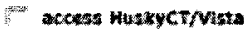

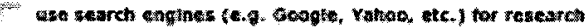

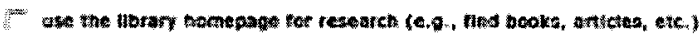

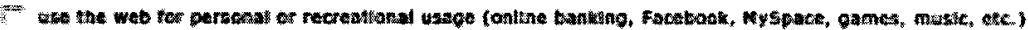

Th chat catine whth a Ihraxus

2. Ust ws once Product (Ward, Excet, powerpelat, atc)

F. I dont use computers on campas

26. Which of the following software applications do you need to complete your assignments? (check all that apply)

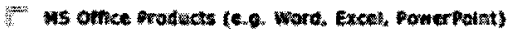

H. Pattiksting sotkware (c.n. Mcrobat)

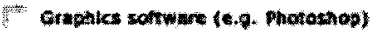

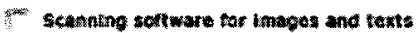

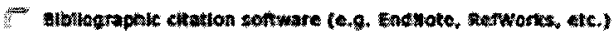

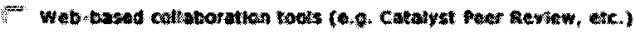

7 statiatical data: (e.e. Mratah, soss, the )

Other tphemse sodity 


\section{UConn Regionals: Learning Commons Survey}

27. If on-campus training sessions were available, what kind of sessions would be of interest to you? (check all that apply)

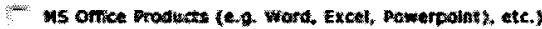

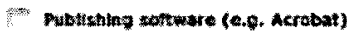

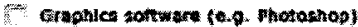

Web ploblahing sortware (e.p. Dreamweaver)

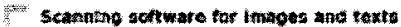

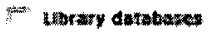

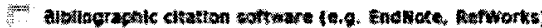

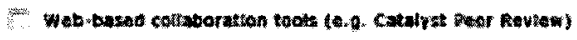

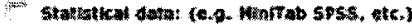

makretrivista

Othe folense woochy)

28. Please let us know what we can do to improve technical support.

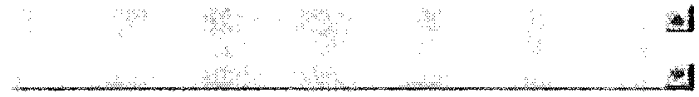

7. PERSONAL INFORMATION

29. Please enter the following information to enter the drawing for the 8GB Silver iPod Nano (3rd Generation).

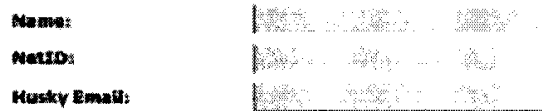

30. Campus Affitiation:

* Avery noms

F) creater Martwate

- Stamtaro

Tormagen

2. Mazterotiry 
From: Regional Campus Library Director

\section{To: [UCONN_STUDENTS-L]}

Subject: WIN A NANO! JUST TAKE OUR SURVEY

This is no gimmick! The libraries at UConn's regional campuses need the help of our students. We need it so much we're willing to give one student at each regional campus an 8GB SILVER NANO - free and with only one string attached. The string? To enter our NANO drawing you must go to the following web link and complete our survey about the Learning Commons, where students will be able to find services that enhance learning, writing, research, and teaching.

After submitting the survey, enter your Husky e-mail address (which will be kept confidential and will not be linked to your survey responses) for the raffle and the lucky NANO winner will be notified by e-mail. It could be YOU!

TO ENTER OUR DRAWING: http://tinyurl.com/2ctsgc

The Fine Print: The survey concludes on January 31, 2008. Entries received after that date will not be included in the drawing. The iPod Nano winner will be notified within 2 weeks after the conclusion of the survey. Only 1 Nano, which will be new in its original packaging, will be awarded for each regional campus. The winner must be a currently enrolled UConn student and must provide verification of student status. The winner must agree to allow the University Libraries to make public his/her name and student status and also to use a photo, if taken, as part of the Libraries' public relations activities. 